\title{
Efeito térmico de plantas trepadeiras no envelope de edificações, como protetores solares de paredes e coberturas e anteparos à ventilação natural ${ }^{*}$
}

\section{Laís Magalhães Tatagiba (IC)}

\section{Resumo}

A proposta desta pesquisa é mensurar a influência da trepadeira nas superfícies externas da edificação, e a interferência no microclima da área externa e interna do objeto de estudo. Foi analisado o comportamento de algumas trepadeiras e sua contribuição para atenuar o ganho de calor no interior da edificação. A análise dos dados obtidos foi feita comparando-se o desempenho térmico de dois protótipos idênticos, com e sem vegetação.

Palavras Chave: Conforto térmico, trepadeira, segunda pele.

* Esse projeto de IC faz parte de um auxílio à pesquisa de doutorado de Denise Damas Morelli.

\section{Introdução}

O revestimento das edificações com trepadeira (segunda pele ou pele-verde) é considerado uma técnica coerente com os princípios de sustentabilidade para o ambiente construído (DESIGN FOR LONDON, 2008).

O objetivo deste projeto é avaliar a contribuição de superfícies vegetadas por trepadeiras para atenuar o ganho de calor no ambiente interno, através de medições das variáveis ambientais, comparando dois protótipos idênticos, com e sem vegetação.

\section{Resultados e Discussão}

A tabela 1 apresenta os valores obtidos na área externa dos protótipos. A tabela 2 apresenta a relação dos valores obtidos na área interna dos protótipos com e sem vegetação. As medições realizadas nas células-teste no período do outono mostram que as maiores temperaturas do ar registradas foram: $33,4^{\circ} \mathrm{C}$ para o ar externo, $30,5^{\circ} \mathrm{C}$ para o protótipo com trepadeira na superfície e $32^{\circ} \mathrm{C}$ para o protótipo sem trepadeira na superfície. A temperatura do ar está diretamente relacionada com a vegetação e cor da superfície(branca). O protótipo com vegetação mostra um resultado para a temperatura média com variação de $2,9^{\circ} \mathrm{C}$ e $\mathrm{o}$ protótipo sem vegetação $1,4^{\circ} \mathrm{C}$ em relação a área exterior. Desta forma, a utilização da trepadeira como segunda pele de superfícies mostrou-se eficiente na redução da temperatura do ar na edificação. A umidade relativa do ar apresentou resultados semelhantes no interior dos protótipos com e sem a vegetação, tornando-se, assim, menos relevante para a análise da relação entre a vegetação e o conforto térmico.

Tabela 1. Média final das medições para área externa.

\begin{tabular}{|l|c|}
\cline { 2 - 2 } \multicolumn{1}{c|}{} & Area externa \\
\hline Temperatura Máxima do $\mathrm{Ar}$ & $33,4^{\circ} \mathrm{C}$ \\
\hline Temperatura Mínima do $\mathrm{Ar}$ & $21.2^{\circ} \mathrm{C}$ \\
\hline Umidade Máxima do $\mathrm{Ar}$ & $57,90 \%$ \\
\hline Umidade Mínima do $\mathrm{Ar}$ & $33 \%$ \\
\hline
\end{tabular}

Figura 2. Média final das medições para área interna: com e sem vegetação.

\begin{tabular}{|c|c|c|}
\cline { 2 - 3 } \multicolumn{1}{c|}{} & \multicolumn{2}{c|}{ Área Interna } \\
\cline { 2 - 3 } \multicolumn{1}{c|}{} & $\begin{array}{l}\text { Sem } \\
\text { Vegetação }\end{array}$ & $\begin{array}{l}\text { Com } \\
\text { Vegetação }\end{array}$ \\
\hline Temp. Máxima do $\mathrm{Ar}$ & $32^{\circ} \mathrm{C}$ & $30,5^{\circ} \mathrm{C}$ \\
\hline Temp. Mínima do $\mathrm{Ar}$ & $24,1^{\circ} \mathrm{C}$ & $24^{\circ} \mathrm{C}$ \\
\hline Umidade Máxima do $\mathrm{Ar}$ & $65,40 \%$ & $66,90 \%$ \\
\hline Umidade Mínima do $\mathrm{Ar}$ & $45,20 \%$ & $48,1^{\circ} \mathrm{C}$ \\
\hline Temp. Superficial Int. Máx. & $25,6^{\circ} \mathrm{C}$ & $25,1^{\circ} \mathrm{C}$ \\
\hline Temp. Superficial Int. Mín. & $19,0^{\circ} \mathrm{C}$ & $18,7^{\circ} \mathrm{C}$ \\
\hline Temp. Superficial Ext. Máx. & $34,3^{\circ} \mathrm{C}$ & $33,8^{\circ} \mathrm{C}$ \\
\hline Temp. Superficial Ext. Mín. & $20,6^{\circ} \mathrm{C}$ & $20,3^{\circ} \mathrm{C}$ \\
\hline
\end{tabular}

\section{Conclusões}

As diferenças entre as medições de temperatura do ar obtidas pelos protótipos com e sem trepadeiras sugerem que a vegetação é um aliado importante para a manutenção do conforto térmico do ambiente. A temperatura interna do ar entre os protótipos apresentou uma diferença de $1,5^{\circ} \mathrm{C}, \mathrm{o}$ que quantifica a eficácia da superfície verde na célula-teste. No entanto, mais pesquisas são necessárias para a quantificação precisa da influencia da vegetação no conforto térmico, avaliando-se todas as estações do ano e aspectos expressivos, como o efeito da vegetação sobre a ventilação no ambiente.

\section{Agradecimentos}

A autora agradece à $\mathrm{CNPq} / \mathrm{PIBIC}$, pelo apoio financeiro (Processo $\left.n^{\circ} 123566 / 2013-4\right)$ para o desenvolvimento desta pesquisa, e também a Doutoranda Denise Damas Morelli e a Profa Dra Lucila Chebel Labaki, do Laboratório de Conforto Ambiental e Física(LACAF), da Faculdade de Engenharia Civil, Arquitetura e Urbanismo da UNICAMP.

${ }^{1}$ DESIGN FOR LONDON. Living Roofs and Walls - Technical report: Supporting London plan policy. London: Greater London Autority, 2008. 